Article

\title{
The Imagination of the Other in a (Post-)Sectarian Society: Asylum Seekers and Refugees in the Divided City of Belfast
}

\author{
Ulrike M. Vieten and Fiona Murphy
}

The Senator George J. Mitchell Institute for Global Peace, Security and Justice, Queen's University Belfast, BT7 1NN, UK; E-Mails: u.vieten@qub.ac.uk (U.M.V.), f.murphy@qub.ac.uk (F.M.)

* Corresponding author

Submitted: 17 January 2019 | Accepted: 17 April 2019 | Published: 27 June 2019

\begin{abstract}
This article explores the ways a salient sectarian community division in Northern Ireland frames the imagination of newcomers and the experiences of asylum seekers and refugees. We examine the dominant ethno-national Christian communities and how their actions define the social-spatial landscape and challenges of manoeuvring everyday life in Northern Ireland as an 'Other'. We argue all newcomers are impacted to some degree by sectarianism in Northern Ireland, adding a further complexified layer to the everyday and institutional racism so prevalent in different parts of the UK and elsewhere. First, we discuss the triangle of nation, gender and ethnicity in the context of Northern Ireland. We do so in order to problematise that in a society where two adversarial communities exist the 'Other' is positioned differently to other more cohesive national societies. This complication impacts how the Other is imagined as the persistence of binary communities shapes the way local civil society engages vulnerable newcomers, e.g. in the instance of our research, asylum seekers and refugees. This is followed by an examination of the situation of asylum seekers and refugees in Northern Ireland. We do so by contextualising the historical situation of newcomers and the socio-spatial landscape of the city of Belfast. In tandem with this, we discuss the role of NGO's and civil support organisations in Belfast and contrast these views with the experiences of asylum seekers and refugees. This article is based on original empirical material from a study conducted in 2016 on the experiences of asylum seekers and refugees with living in Northern Ireland.
\end{abstract}

\section{Keywords}

asylum seekers; Belfast; ethnic identity; gender; imagination of the Other; nationalism; refugees; sectarian omni-presence

Issue

This article is part of the issue "The European Refugee Controversy: Civil Solidarity, Cultural Imaginaries and Political Change", edited by Gert Verschraegen (University of Antwerp, Belgium) and Robin Vandevoordt (University of Oxford, UK/University of Antwerp, Belgium).

(C) 2019 by the authors; licensee Cogitatio (Lisbon, Portugal). This article is licensed under a Creative Commons Attribution 4.0 International License (CC BY).

\section{Introduction}

In recent years, a heightened moral panic (Garland, 2008) has emerged with respect to the so called, 'refugee crisis', or as we suggest herein what is in fact, a 'border crisis,' a term which indicates a failure of particular nation states or supra-national organisations such as the EU to respond ethically to conflict and the massmobilisation of people from other regions. According to Yuval-Davis and Vieten 'This crisis is at the heart of relationships between states and societies and to con- structions of subjectivity and thus needs to be seen as a doubly-related crisis of both governability and governmentality' (2018, p. 70). Triggered by different layers of social, economic and political crises, the world has been confronted by a backlash to cosmopolitan and multicultural concepts of plural and diverse societies coupled with a rise of far-right extremist political parties in different countries. One expression of this ideological shift to a far-right populist 'politics of fear' (Wodak, 2015) is a gendered moral panic in the form of blaming newly arrived male refugees for crime, and in particular, for 
the physical and sexual harassment of white, Christian women in European public spheres (Vieten, 2018). Anchored in the current wave of far-right populisms and the growth of extreme right parties this gendered controversy confronts us with the legacy of Orientalism (Said, 1978), mainstream anti-Muslim racism (Poynting \& Mason, 2006; Vieten, 2016) and-as far as Europe is concerned-'archives of European racisms' (Vieten, 2011). As such, a number of critical questions, which inform our reflection herein, need urgent answering, for example, how the 'Other' is imagined in different European societies and what that means for the perception and welcoming of asylum seekers and refugees. Further, a key question is what kind of learnings can we glean from the situatedness and ideological dimension of (gendered) othering from various societies across Europe? While continental Europe is mostly identified with Europe (or enmeshed with the European Union), a similar proxy exists when thinking of the United Kingdom (UK) of Great Britain and Northern Ireland. People might say the 'UK', but in fact what they have in mind is mainland Britain (Scotland, Wales and England). When we say 'Ireland', the average European lay person might think of another island, geographically (south and north), and thereby might find it difficult to comprehend that there is still a political space on the same island, 'belonging' to the UK: Northern Ireland. This has become particularly obvious during the Brexit crisis, with a clear lack of understanding of the relationship of Northern Ireland to both the Republic of Ireland and Great Britain having become startingly evident.

Despite its marginality, since 2016 Northern Ireland has newly been the subject of much discussion and debate in the UK, as well as received coverage by international and European media. Largely, this has to be understood in the context of the UK/GB decision to leave the EU. Underpinned by the political party strategy of the Democratic Unionist Party (DUP), the dominant loyalist political party in Northern Ireland, has been in support of the British Prime Minister, Teresa May's, ToryConservative minority government in Westminster, since 2017. At the time of writing, the political future of the current Tory government is in turmoil. The decisive role of the DUP connects to the model of consociationalism enshrined as political mandate in Northern Ireland since 1998.

It is these complexities and the geographic focus of Northern Ireland that informs this piece. As people living in Northern Ireland and the Republic of Ireland, we believe that issues such as the rise of the far right, Brexit, and the ongoing legacies of the Northern Ireland conflict impact asylum seekers and refugees' everyday lives in Northern Ireland in quite distinctive ways. However, as social scientists living through and observing the intersecting crises of conflict, displacement and the rise of the far right, our aim in this article is to move beyond the moral panics surrounding such crises in order to critically examine how the particularities of Northern Ireland, especially the issue of sectarianism, present very specific challenges for asylum seekers and refugees. We are also concerned with how narratives of post-conflict and reconciliation in Northern Ireland hamper deeper discussion of these issues with respect to all people living on the island of Ireland, established communities and newcomers alike.

In the Northern Ireland context, questions with respect to the notion of difference and the situation of newcomers continually arise, specifically about the ways in which social and political divides anchored in sectarian mindsets impact newcomers to Northern Ireland. Key questions exist regarding the imprint and the consequence of this differently anchored, extremely divisive, imagination of community, which does not reflect Anderson's (1983) often cited notion of the 'imagined community'. Additionally, this connects to how the meaning of gender, or intersectional positions, and the imagination of the Other, unfold in different ways. The research for this article took place in Belfast and Derry/Londonderry ${ }^{1}$ in 2016 and we draw on this empirical data for this article. Our research data was collected through a commissioned research tender for the Racial Equality Unit in Stormont (Office of the First and Deputy First Minister), Northern Ireland. A steering group comprised of a number of charities and NGOs across Northern Ireland oversaw the research process for the duration of the project. This process of having regular meetings with an advisory board anchored in civil society provided revelatory insights into the challenges for this sector in Northern Ireland, but also generated conversations useful for our broader academic research. The project was largely qualitative with a short quantitative Northern Ireland wide survey targeting civil sector society whose scope was to feed into the development of a refugee integration strategy. Currently, Northern Ireland is one of the only jurisdictions in the UK which does not have a refugee integration strategy (Murphy \& Vieten, 2017), and has been without a regional devolved government since January 2017. A refugee integration strategy was drafted from our research report, but is, at the time of writing (March 2019), currently waiting to be implemented due to the political stalemate in Northern Ireland.

Herein, we argue that all newcomers, apart from the established majority and minority communities are affected by an ideological sectarian divide. Given the particular vulnerabilities of asylum seekers and refugees, especially as dedicated asylum housing is often located in sectarian areas-we posit that the everyday lives of asylum seekers and refugees are deeply entangled with the vagaries of sectarianism and its associated politics. While living in legal and economic limbo asylum seekers depend on local institutional provisions, and everyday sectarian culture impacts on their lives, often in unforeseen ways. First, we review some conceptual debates on the

\footnotetext{
${ }^{1}$ In the hegemonic language Derry is called Derry/Londonderry.
} 
notion of the Other, gender and the role of national imagination with respect to Northern Ireland. Then, we briefly talk about the spatial complexities of Belfast with respect to the sectarian divide, social divisions, and highlight the dearth of a holistic approach to combat race hate crimes. Third, we contextualise the phenomenon of immigration to Northern Ireland with a focus on migrants who have fled persecution and war in their countries of origin and illustrate how sectarianism and the imagination of the Other framing perspectives of everyday life in Belfast. In the fourth section, we present some of the findings of our research. We concentrate here on the views of service providers and activists of local NGOs supporting asylum seekers and refugees and contrast these views with the experiences of asylum seekers and refugees. We conclude with some precautious remarks on what that means to the temporary and situated ideological construction of the (gendered) Other, e.g. with respect to the situation of refugees in (Continental) Europe.

\section{Imagining the Other: Ethnicity, Gender and 'Nation' in Northern Ireland}

In their important discussion on cosmopolitanism, Szerszynski and Urry (2002) also engage the concept of nationalism positing that 'the system of nation states and national identities involved antagonism towards the "stranger", especially those strangers deemed to have a different colour, creed or culture.' (p. 462) Whereas mainstream and male theorists of nationalism and the modern nation state largely ignored the built-in ideological function of gender (see, for example, Gellner, 1983; Hobsbawm, 1992) feminist theorising (McClintock, 1995; Yuval-Davis, 1997, 2011) on the relationship between gender and nationalism has become more prominent since the 1990s. Yuval-Davis' (1997) seminal ${ }^{2}$ text 'Gender and Nation' is pivotal to unpack these structures as her analysis helps to understand contemporary constructions of gendered community boundaries in the West, in Europe and beyond. Yuval Davis argues that 'the woman' is primarily identified with particular ethnonational communities as motherhood carries the biological and symbolic representation of the nation and becomes intertwined with a nation's sense of morality and honour. While referring to the Algerian war of independence and the contested debates on the veil, then and now, Calhoun (1997, p. 113) contemplates 'more generally, it suggests reasons beyond simple patriarchy for the tendency of nationalist movements so commonly to affirm masculinist practices rooted in traditional cultures (see also Chatterjee, 1994).' Erel (2018) proposes that the gender conservative or even anti-gender rhetoric of the far right and mainstream right parties is blurred, and that social, cultural and national reproduction is bounded to the way gendered and ethnic relations are constructed, and how and why migrant families are positioned as Others. If we agree with Erel (2018), who argues that 'gender imagination of the nation have [sic] been instrumental in reconciling contradictory aspects of the nation' (p. 174), what does this mean when applied to the context of Northern Ireland, where the legacy of the violent conflict, called the 'Troubles', posits two adversarial ethno-national religious communities, vis a vis other Others?

Rooney $(2006,2007)$ and other feminist scholars (Hinds, 2014; Kennedy, Pierson, \& Thomson, 2016; Ward, 2015) have analysed Northern Irelands' conservative gender regime which they posit impacts all relevant public and semi-public spaces such as media, legislation (justice), policy, academia and politics. According to Rooney (2007):

The invisibility of women in conflict narratives and the absence of gender awareness in the transitional context is core to understanding how women's dayto-day lives get left out of consideration in the context of negotiations. The precarious role of women in conflict discourses maintains the invisibility of gender regimes operating within conflict scenarios. This precarious role is vital to the sustenance of the narrative fiction that conflicts are gender-free. (p. 98)

This 'invisibility of gender regimes' certainly impacts the perception of difference and otherness. As we argue here, 'othering', and the imagination of the Other, has to be analysed differently as there is another 'Other' historically constructed in the visibility of the 'Other' established ethnonational collective in Northern Ireland society. The 'legacy' of sectarian violent conflict and the appeasement politics of consociationalism, focusing on the two majority Christian ethno-national communities in Northern Ireland, in effect, means that there is lack of a cohesive understanding of one nation (Yuval-Davis \& Vieten, 2018). Nevertheless, even without having a cohesive narrative of a single nation, the (gendered) imagination of community boundaries in Northern Ireland operates within a patriarchal frame policing female bodies according to the normative assumptions of the two intra-Christian ethno-national communities. Strict antiabortion laws and an anti-gay marriage consensus ${ }^{3}$ in Northern Ireland (different to both Britain and the Republic of Ireland) are expressions of a gender regime that assigns different expectations and social roles to men and women. Intertwined with the persistence of a sectarian split it seems therefore that gender is not placed at the heart of male and mainstream debates

\footnotetext{
2 Farris' (2017) work addresses the pitfalls of contemporary liberal feminism supporting mainstream anti-Muslim politics and policy, in France and the Netherlands, for example. However, here we are discussing the symbolic positioning of 'the woman' as cultural boundary marker of a national imagination, and as belonging to specific ethno-national communities, which is more relevant to the situation in Northern Ireland.

${ }^{3}$ The anti-gay marriage and homophobic political landscape of Northern Ireland means that Puar's (2007) focus on 'homo-nationalism' referring to an ideological support of some members of gay communities for mainstream anti-Muslim discourses as it is growing in some countries is not the main angle of our debate as far as Northern Ireland is concerned.
} 
on sectarianism and consociationalism. In consequence, academia, policy and politics underestimate the ideological function of hegemonic masculinities and femininities in containing the status quo of the sectarian politicalsocial landscape of Northern Ireland. This is the ideological frame that shapes the relationships of established communities and newcomers alike.

\section{Northern Ireland and the Continuity of Sectarian Tension: The Landscape of Belfast}

The issue of sectarianism lingers long in the Northern Ireland imagination, as does the political appeasement constructed to comfort both ethno-national communities, post-1998, which is called consociationalism (Garry, 2012; O'Leary, 2005). Both concepts might be of less interest abroad, but after the violent conflict called The Troubles ${ }^{4}$, in 1998, the Good Friday Agreement settled for a more peaceful outlook and cooperation between the two dominant ethno-national communities, the Catholic Republicans, and the Protestant Unionists, the latter loyal to the UK/GB and wishing to keep this Union. As part of the 1998 Peace agreement, the citizen rights of Catholics were ameliorated, and with consociationalism and anti-discrimination law institutionalised, Northern Ireland now strives to establish parity between the two communities. Interestingly, post-1998, Belfast saw a rise in ghetto-like homogenous neighbourhoods (Murtagh, 2011), as some ethno-national communities prefer to live amongst one another. This restructuring of the landscape, for example, in Belfast, created-either on purpose or as a side effect-highly sectarian local spaces across the city. O'Dowd and Komarova (2009, p. 7) note, 'The longevity of communal territories and their boundaries, and of the struggles to control them, is testimony to enduring significance of sectarian territoriality in Belfast.' Shirlow (2006) regards the social-spatial segregation of Belfast as an ongoing rupture to a normal use of the city space for its urban citizens. In consequence, the urban environment is defined by historically loaded group identities and so called 'shared space' is confined to inner city, mainly shopping miles and consumerist, areas. By drawing on the work of Bell (1990) and Boal (1996), Smyth and McKnight (2013, p. 307) describe the signifiers of post-Troubles community conflict in everyday situations as follows:

Many ordinary activities, such as standing at specific bus-stops, using particular playgrounds or parks, wearing specific school uniforms, football shirts, remembrance poppies or St Patrick's Day colours, all carry the potential of low level [sic] hostility and conflict.
Everyday encounters with sectarianism might occur in any local public space, and particularly in neighbourhoods where family and social life takes place as Smyth and McKnight (2013) emphasise. These kind of everyday life encounters shape housing and livelihood in more socially deprived, working class areas in West and North Belfast. That means that the spatial confrontation with sectarian performance is classed and gendered and dependent on where, and how you move through the city. As indicated above 'gender' rather is absent in the Northern Ireland public discourse when it comes to the political business of sectarian parties and public debates on violence. As such, the classed gender of sectarian activities rarely is spelled out. A report in 2007 (cited in Montague \& Shirlow, 2014) showed that sectarian divisions cost Northern Ireland $f 1.5$ billion each year. Predominantly, these costs are associated with the rituals of sectarian social identities (e.g. 13 July marches, 12 July bond fires) and with this an ongoing adversarial community organisation is creating immense economic, but also social costs for the public.

Beyond the 'cultural' display of distinctive ethnonational community identities in local public spaces, e.g. flagging, July parades and bond fires, hate crime is an ongoing issue. Here, sectarian violence is understood as the violence enacted against members of the established two communities (e.g. Loyalist/Protestant and Republican/Catholic), e.g. focusing on 'religious' divisions. By contrast, race hate crime highlights a different quality of attacks on 'newcomers': all Others, equally black people, white or black EU citizens-migrants, refugees and asylum seekers might be victims of those attacks. Further, travellers are mentioned in the Police Service of Northern Ireland (n.d.) reports as a separate ethnic group, outside of the two sectarian communities. These distinctions are problematic as they sub-divide groups that are affected by different forms of violence without looking at the broader picture of a sectarian omni-presence. There is very little research extant, to substantiate the links between religiously segregated places and racism (McVeigh \& Rolston, 2007; with respect to encounters of difference, Piekut \& Valentine, 2017). The media, however, has drawn a number of links between divided areas and an increase in racism. This means that newcomers, and this applies particularly to asylum seekers and refugees, are fearful about being housed in certain areas even without ever having visited them (Murphy \& Vieten, 2017). But it also means that it is difficult to talk about these anxieties with service providers as long as sectarianism is not accepted as an everyday issue affecting all newcomers as much as established communities.

Belfast carries the legacy of 'The Troubles' and its violent conflict has distorted the urban landscape, making it seemingly ill-equipped to manage the arrival of larger

\footnotetext{
${ }^{4}$ The hegemonic term 'The Troubles' could be also read as euphemism. Catholics were institutionally discriminated in Northern Ireland, and the violent conflict started after a peaceful demonstration for civil rights and the demand to end institutional discrimination of Catholics. Police attacked civilians, and thereafter, from 1969 on and for three decades, military police and para-militaristic attacks on people in Northern Ireland, Ireland, England and also Europe, defined the everyday life.
} 
scales of newcomers. The civil society and social fabric continue to be defined by the legacy of the violent conflict and a politics that is centred on the appeasement of the two dominant ethno-national-religious communities whilst largely ignoring the place of gender in constructing community boundaries inside, and against Others. In the next section, we briefly contextualise immigration to Northern Ireland with a focus on migrants who have fled persecution and war in their countries of origin in the 20th and 21st Century.

\section{Newcomers to Northern Ireland: EU Migrants and Asylum Seekers}

Though Northern Ireland largely appears as a white homogenous society-there are long established ethnonational minority communities of Chinese (Delargy, 2007) and Indians (Delargy, 2008; Marger, 1989). Jews, for example settled in Belfast in the 1860s, and Northern Ireland has also welcomed boat people from Vietnam (see for details Murphy \& Vieten, 2017). However, it is only since the Good Friday Agreement of 1998 that Northern Ireland is regarded as a more peaceful society (Brewer, 2010), and now attracts more immigrants (Malischewski, 2016). Recent years have seen a larger number of workers moving from the A8 countries (in particular Poland), post-2004, based on EU citizen freedom rights (cross-border mobility), as well as a higher number of asylum seekers and refugees. Belfast hit the international media headlines in 2005, following several racist attacks on Roma in South Belfast. According to Russell (2016), a higher number of Roma-estimated are about 1000 living in Northern Ireland-settled in Belfast, e.g. particularly 'in the Botanic Lower Ormeau areas of South Belfast' (2016, p. 14).

It is crucial therefore to recognise that Northern Ireland is now a culturally more diverse region. The ongoing process of normalisation also means that since the 2000s asylum seekers consider staying in Northern Ireland. Through the Vulnerable Persons Relocation Scheme Syrian refugees have arrived as programme refugees to make a new life in Belfast and Derry. In 2018, there were approximately 700 asylum seekers living in Northern Ireland (mostly residing in Belfast), with an average of 200-300 new applications per year. While this represents less than 1 per cent of the overall UK figures, the accommodation of asylum seekers and refugees and the 'integration' of the latter, nonetheless poses challenges for state policy, social institutions and employers in Northern Ireland, particularly given Northern Ireland's status as a post-conflict/divided society. There is some research on the spatial dimensions of settlement for asylum seekers and refugees (Franklin, 2014). The areas in which asylum seekers and refugees are housed impact on access to employment and health, as well as broader social networks with the host community and other members of the asylum and refuge seeking community. The spatial complexities of Northern Ireland are com- pounded by its history. Belfast as a city with high levels of spatial segregation as indicated above can be a complex place for asylum seekers and refugees to live and settle in. Often asylum seekers and refugees are housed in lower quality housing in underprivileged areas with high levels of segregation. In the context of Belfast, where there are higher levels of National Asylum Support Service (NASS) accommodation, South Belfast has become somewhat of a hub for asylum seekers and refugees and also a number of civil society sector organisations supporting them (see also Kerr, 2013). In summer 2018, a number of Syrian refugees-part of the VPR Scheme-spoke publicly about the alarming housing situation and racist attacks in Belfast (Morris, 2018). Though North and West Belfast often are referred to when speaking about sectarian neighbourhoods it seems that South Belfast, too, hosts sectarian and racist pockets that are not welcoming to newcomers (Roma/EU migrants, and Syrian refugees). In what ways are asylum seekers and refugees affected by sectarianism and sectarian omni-presence and racist violence in Belfast? Do they feel as 'the Other' in Northern Ireland, and what do service providers do in order to make them feel more welcomed?

In the remaining part of the article we introduce more details of the methodological approach, followed by a discussion some of the findings.

\section{Researching Difference}

For this research, we conducted semi-structured interviews with 48 asylum seekers and refugees from ten different countries, including-Somalia, the Sudan, Kenya, China, Zimbabwe, Kazakhstan, Sri Lanka, Nigeria, Iran and Syria. Further we spoke to 50 members of the $\mathrm{NGO} /$ Charitable sector and service providers (health, education, labour and housing) in Northern Ireland. Asylum seekers and refugees interviewed have lived in Northern Ireland from a period of three months-ten years (with two having achieved naturalisation; full citizenship). We interviewed both male and female asylum seekers and refugees and conducted a mix of single and mixed gender focus groups.

The spread of interviews across different kinds of civil sector organisations-religious charities, volunteer groups, and NGOs and service providers working in different spaces provided very clear and broad insights into the supports extant for asylum seekers and refugees. Our research approach was informed by the methodological construct of intersectionality as well as the author's professional orientations as social scientists (a sociologist and an anthropologist). We used the notion of intersectionality as a lens through which to analyse and document the life worlds of refugees and asylum seekers in Northern Ireland. We posit that the feminist concept of 'intersectionality' (Crenshaw, 1991; McCall, 2005; Vieten, 2008) provides a critical conceptual and methodological toolbox through which to analyse a plurality of individual subjectivities whilst also shedding light on the 
structural order of social inequality. The most relevant analytical entry points for us as researchers were the overlapping social divisions which include: nationality, legal status, gender/sex, sexuality, class, religion, ethnicity/race; age and location. The two field sites were chosen for different reasons: Belfast is home to the largest number of asylum seekers and refugees in Northern Ireland and is a city that continues to be highly segregated along religious and national lines with Protestant and Catholic communities often living in distinct areas in the city (McNulty, 2016). Belfast also has a larger number of voluntary sector organisations working with asylum seekers and refugees, and this facilitated contact with research participants. We also undertook some short field visits to Derry/Londonderry and Craigavon as there are a growing number of asylum seekers and refugees located there (McNulty, 2016). Derry/Londonderry, in terms of its proximity to the Republic of Ireland and the Irish border, also provided some interesting data specifically related to the challenges of living so close to a border. We used a process of grounded theory to analyse our interviews and focus groups utilising both inductive and deductive techniques. Such a process permitted patterns of data to be identified through reading and re-reading of texts, allowing both descriptive and analytical accounts of asylum seekers and refugees lives in Northern Ireland to be developed. According to Malischewski (2013), who conducted a small-scale study in Northern Ireland (on asylum seekers and refugees), the perceived homogeneity of groups poses one of the main challenges of this kind of research. She argues $(2013$, p. 6) that:

The Northern Irish case presents a dramatic example of social division, one in which the question of 'what' refugees and asylum seekers are integrating into is particularly poignant. Indeed, though sectarianism plays an overarching role in dividing society, other factors such as age, gender, class, race, and ethnicity also contribute to social positioning and division.

It is this argument of intersectional social divisions that inflected our study of the particular situation and experiences of asylum seekers and refugees in Northern Ireland in 2016.

\section{Conversations with Civil Society}

A particular aspect of our original research was to examine the role of civil sector society and state bodies in the support and integration of asylum seekers and refugees. Northern Ireland is home to a large body of NGOs and volunteer groups, some of this is a legacy of the conflict in Northern Ireland. State supports for asylum seekers and refugees are in line with broader supports in the UK, even though Northern Ireland remains outside of the broader system of dispersal. Beyond measuring the status quo of service delivery, our research went deeper, in terms of discussions with civil sector organisations and service providers on some of the very specific challenges that Northern Ireland, as a post-conflict society, presents for asylum seekers and refugees. Some of these discussions, were unsurprisingly, revealing of how issues of sectarianism impact on the perception of asylum seekers and refugees. While a number of our research participants spoke openly about this, others asked for their comments on this topic to be anonymized as they did not want to be identified in their workplace as someone openly discussing this particular issue. Invariably, in all of our interviews the issue of sectarianism arose, even though it was not one of our formal questions in our interview schedule. In some cases, it went as far as respondents denying the idea that Northern Ireland's experience of sectarianism was in anyway impactful on asylum seekers and refugees. With one NGO worker stating:

I do not believe sectarianism impacts on asylum seekers and refugees. I'd like to see how Belfast compares to somewhere like Glasgow, which is also a sectarian city. Or even, how does it compare to the experience of asylum seekers and refugees living in an underprivileged area of Dublin? No, I don't think sectarianism is something that comes into play in asylum seekers and refugees' experiences here in Belfast. (NGO Professional, 2016)

As we show in this article and elsewhere (Murphy \& Vieten, 2017), asylum seekers and refugees themselves frequently point to how the particularities of Northern Ireland as a post conflict, sectarian society impacts their everyday. What we call-'the sectarian omnipresence' shapes expectations of relationships, and possibilities to move safely through space.

The everyday life experiences of asylum seekers and refugees are affected foremost when confronted with spatial segregation. It results in no-go areas, or as far as housing and neighbourhoods are concerned anxieties of asylum seekers and refugees of where to live, and at best stay in South Belfast, where most of the local ethnic networks are located, near Queen's University Belfast. Given the pressure on the housing system, this is not always possible and so asylum seekers and refugees find themselves living right across the city. The reasons why newcomers, and particularly asylum seekers choose South Belfast are complex and related among others to this area being perceived as a 'mixed' neighbourhood, more multicultural-with different communities of students and visible internationals living near Queen's University and in the Botanic Quarter. This neighbourhood has become somewhat of a hub for asylum seekers and refugees and also a number of civil society sector organisations supporting them (see also Kerr, 2013).

The assumption that it is difficult for visibly different refugees to settle in certain neighbourhoods is an idea perpetuated by host community members as much as by anyone else. As one female research participant articulates it: 
We had a friend actually who was saying who lived in north Belfast, his dad was really old. And he was saying to me if my area was okay for you, I would have given you my daddy's house for the time being until you get a permanent home, which was very kind of him. But then he said people might not receive you around there so I don't want to cause you problems. So he couldn't give us that house. And also he had a landlord who had a nice apartment in north Belfast which was manageable. Their rent was reasonable. But I did not want to change the school. And then he said the colour might cause a problem when the children come back from school. The colour of the uniform. (Sudanese refugee, L.)

The projection of a sectarian threat (the sectarian omnipresence) is running through these lines. Our interview partner perceived North Belfast with its majority of sectarian Loyalists and as a white working-class neighbourhood as being more adversarial towards asylum seekers than other neighbourhoods in Belfast. It might be striking, too, that the meaning of 'colour' with respect to 'uniforms' is introduced here as even more threatening than 'colour' of the skin as everyday racism. While anecdotal, what $L$ says, in effect means that alternative sources of accommodation become unavailable due to sectarianism and racism. As a female black refugee, L's testimony is echoed in other strands of our research. Living alone with her children as a single mother whilst facing the challenges of being housed in a sectarian area was an issue a number of our other female research participants pointed to. Our research highlighted that asylum seekers are subject to multiple, often indiscriminate house moves which creates further instability for their families. The intersecting positions with respect to gender/sex (female), race (black), legal status (seeking asylum) and being a parent (mother) shapes possibilities of movement and settlement, even if it is temporarily. The issue of walking through sectarian areas clad in a religious school uniform of the wrong orientation was flagged in a number of our interviews by mothers fearful of what might happen to their children if deemed 'Catholic' in a loyalist area or vice versa, 'Protestant' in a republican area. A number of our research participants were in fact single mothers and therefore, subject to both the everyday structural violence of mothering alone in a conservative society as well as being forced to live in substandard asylum accommodation in sectarian and often, conflictual spaces. In Northern Ireland, and in line with other UK jurisdictions, accommodation is decentralised, and asylum seekers live in a variety of privately rented flats or in social housing. The Northern Ireland Housing Executive runs an extra funded program (Refugee Floating Support) to ease 'the transition to a more permanent relationship to Northern Ireland' (Murphy \& Vieten, 2017). As accommodation for asylum seekers in Northern Ireland is funded through the NASS moving into accommodation is dependent on the stage of the asylum application. If granted refugee status people have to move out from provided accommodation during a 28-day period. But, what does this mean when trying to establish bonds with members of local communities?

Another male research participant shared with us how sectarianism has impacted his ability to settle in Belfast:

It does affect me because, especially because now for me, I have a child with an Irish woman...because she wouldn't go to Protestant areas, which limits my movement with my daughter, to wherever I want to go and definitely, it affects me too much, because I used to and I stay in.... lot. Like if I go looking for a house now, she's not happy because of where I'm going to take, do you know what I mean? (Kenyan Refugee, M.)

When thinking of relationships that develop, or in M's case, finding love, making a home and starting a family with a child, the effects of the sectarian omni-presence becomes an everyday issue. As soon as newcomers settle down and come to know individuals from 'local' settled communities they are all too often confronted with prominent ethno-national divisions.

These testimonies, and there were more of them, largely stand in contrast to what service providers presented to us. The claim that sectarianism does not make a place quite uniquely different or less tolerant was one that we met with frequently from civil sector professionals over the course of our research. In the case of the NGO professional cited above, his broader denial of the role that sectarianism plays in shaping asylum seekers and refugees' experiences of Northern Ireland also extended into a gender blindness regarding the specific experiences of male and female refugees. When attempting to unpick the problematics of his rather ideological stance, our conversations with him ended abruptly. This gender blindness emerged a number of times in different conversations with some of our (male and white) civil sector research participants. It was also very visible in issues pertaining to health and employment as well as child care provision. Many of our female asylum seeker and refugee research participants highlighted issues with the use of male interpreters (or in a number of cases, fathers and sons were asked to do this) during their interactions in hospitals. This is an issue we broached with a number of civil society groups, in some instances, only to be told that this had been addressed and dealt with a number of years ago. In practice, however, our research found that this was often not the case and women, in particular, were being put into possible spaces of discomfort, even fear/risk with the inappropriate use of male interpreters around female health issues. This blindness also extended into other spaces with educational or employment training providers not always understanding the needs of women, in particular single mothers, around child care. This issue, however, is something which the 
civil sector groups we worked with were seeking to remedy to the best of their abilities. Questions of funding or a lack thereof continually blight the provision of such necessary elements of services for asylum seekers and refugees, and our research found that, it was female asylum seekers and refugees that are often most adversely impacted by such issues.

Such intersections between sectarianism and gender blindness make for a complex picture for many of our research participants. While a number of our civil sector research participants were acutely aware of these challenges, other interviewees argued that it was not sectarianism but rather a deeply anchored, all pervasive culture of mistrust which impacted most the experience of asylum seekers and refugees in such communities:

One of the main issues in these communities is that people are still afraid, years of not being able to trust nearby neighbours, it's probably normal that people still have not learned how to trust one another or even newcomers. (Health Professional)

In addition to the question of trust was the notion that Northern Ireland needs a better way of defining and operationalising the notion of integration-one which does not make invisible people's presence rather instead, would work to embrace diverse values and ideals outside of the parameters of the so-called 'two community' worldview:

We have to respect people's cultures, traditions, and their reasons to come here and we have to respect their languages. We don't want them to become white Catholics or white Protestants. We want them to be what they are and recognise and value their contribution to our society. (Health sector professional)

The service providers we spoke to, defined the idea in their own terms and language and then connected it to what they saw as the main issues for 'integration' in Northern Ireland. A recurring theme in our interviews was the issue of what exactly asylum seekers and refugees were being asked to integrate into in Northern Ireland, especially given the ongoing challenge of sectarianism. One voluntary sector professional outlined the challenges as follows:

There are still certain areas where they don't have any respect for anybody who is of difference. They don't even respect their own. So, like there is a big divide between Catholics and Protestants. Then on top of that they have other issues with migrant and refugee and the very well settled BME communities like Indian, Chinese, Jewish, Pakistani community who have been here from 1940s and they're very well settled. (Voluntary sector professional)
Implicitly, however, this very clear boundary drawing is also responsible for positioning the 'Other' (all Others), as static and bounded, outside of the integration imaginary (if such a thing can be said to exist). Though the local conditions in Belfast and Derry/Londonderry are very distinctive (Murphy \& Vieten, 2017), the overarching picture was that the omnipresence of sectarianism and associated social-spatial divisions frames a principal boundary between established communities and newcomers, e.g. asylum seekers and refugees.

\section{Concluding Remarks}

The construction of difference, and therefore, processes of othering, are historically situated (Vieten, 2012; Vieten \& Valentine, 2016) and have to be contextualised in terms of particular geo-political spaces. In this article, we have discussed the ways in which the Northern Ireland legacy of conflict and sectarianism continually imprints public and political discourse (e.g. consociationalism) and shapes everyday life, particularly that of asylum seekers and refugees. It is these striking linkages between a culture of distrust and constructs of othering across space and time that we have found in our study. High levels of community and domestic violence, unemployment and poverty have created a legacy of mistrust that constitutes a driving force in generating suspicion of the Other. This intertwined with a layering of different kinds of invisibilities means the position of asylum seekers and refugees in Northern Ireland is highly precarious. While this is similar in other nation-states, in Northern Ireland this is a precarity heightened by sectarian divisions and gender blindness. For many of the female asylum seekers and refugees whom we interviewed this precarity is further compounded by a lack of understanding of their positionality-cultural, social and economic. Unlike other European countries, Northern Ireland hosts only a small numbers of asylum seekers and refugees, and as such, the gendered moral panic so visible in other nation-states has not become central to the main debate on asylum and refuge. Quite the opposite, for better or worse, the absence of gender in approaches to contemporary policy and politics means that 'the Muslim male Other' has not received populist far-right attention, so far, however, race crime on Muslim groups has increased in Northern Ireland. As argued elsewhere (Yuval-Davis \& Vieten, 2018) there is not (yet) an established imagination of one cohesive and uniting political community that constructs itself against the Other. Sectarianism and the political framework of consociationalism (Angelov, 2004) shape how everyday life as well as policy and governance are organised in Northern Ireland (McGarry \& O'Leary, 2006; see for a detailed critique Kennedy et. al., 2016). We do not know yet in what ways post-Brexit Northern Ireland might see a shift in this regard as an increase in articulations of xenophobia and social distress will further impact the perception of the 'other' e.g. the welcoming or rejection of asylum seekers and refugees in future. 


\section{Acknowledgments}

We would like to thank the three independent external reviewers and the co-editors for their helpful advice, and all the detailed comments which greatly helped to evolve this piece. We would also like to thank the Racial Equality Unit at the Executive Office, Stormont, Northern Ireland for their funding of the research upon which this article is based. Further, we are very grateful to all interview partners for their trust, and to the RAs, who supported us in collecting the data in 2016, after all Tal Avrech and Jennifer Greenaway.

\section{Conflict of Interests}

The authors declare no conflict of interests.

\section{References}

Anderson, B. (1983). Imagined communities: Reflections on the origins and spread of nationalism. London: Verso.

Angelov, D. (2004). Problems of consociationalism from the Netherlands to Macedonia. Balkanalysis. Retrieved from http://www.balkanalysis.com/blog/ 2004/02/17/problems-of-consociationalism-fromthe-netherlands-to-macedonia

Bell, D. (1990). Acts of union: Youth culture and sectarianism in Northern Ireland. Basingstoke: Macmillan.

Boal, F. W. (1996). Integration and division: Sharing and segregating in Belfast. Planning Practice and Research, 11(2), 151-158.

Brewer, J. (2010). Peace process: A sociological approach. Cambridge: Polity Press.

Calhoun, G. (1997). Nationalism. Buckingham: Open University Press.

Chatterjee, P. (1994). The nation and its fragmentsColonial and postcolonial histories. Princeton: Princeton University Press.

Crenshaw, K. (1991). Mapping the margins: Intersectionality, identity politics, and violence against women of color. Stanford Law Review, 43(6), 1241-1299.

Delargy, M. (2007). Language, culture and identity: The Chinese community in Northern Ireland. In M. Nic Craith (Ed.), Language, power and identity politics (pp. 123-145). London: Palgrave Macmillan.

Delargy, M. (2008). Do you speak Bollywood? Perceptions of the Indian community in Northern Ireland. Irish Journal of Anthropology, 11(1), 21-27.

Erel, U. (2018). Saving and reproducing the nation: Struggles around right-wing politics of social reproduction, gender and race in austerity Europe. Women's Studies International Forum, 68, 173-182.

Farris, S. R. (2017). In the name of women's rights. The rise of femonationalism. Durham: Duke University.

Franklin, M. (2014). Concepts of displacement and home: Seeking asylum and becoming a refugee among the host community of Northern Ireland (PhD Thesis).
Queen's University, Belfast.

Garland, D. (2008). On the concept of moral panic. Crime, Media, Culture: An International Journal, 4(1), 9-30.

Garry, J. (2012). Consociationalism, regional integration and voter choice. Acta Politica, 47(2), 113-127.

Gellner, E. (1983). Nations and nationalism. Oxford: Blackwell Publishing.

Hinds, B. (2014). Northern Ireland: A transformative strategy for women, peace and security. openDemocracy. Retrieved from https://www.opendemocracy. net/5050/bronagh-hinds/northern-irelandtransformative-strategy-for-women-peace-andsecurity

Hobsbawm, E. J. (1992). Nations and nationalism since 1780: Programme, myth, reality. Cambridge: Cambridge University Press.

Kennedy, R., Pierson, C., \& Thomson, J. (2016). Challenging identity hierarchies: Gender and consociational power-sharing. The British Journal of Politics and International Relations, 18(3), 618-633.

Kerr, M. (2013). A proposal for a refugee integration strategy for Northern Ireland. Belfast: Northern Ireland Strategic Management Migration Partnership. Retrieved from http://www.migrationni.org/ DataEditorUploads/Refugee\%20Integration\%20 Strategy\%20Proposal\%20Final.pdf

Malischewski, C. A. (2013). Integration in a divided society? Refugees and asylum seekers in Northern Ireland (Working Paper Series, No. 91). Oxford: Refugee Studies Centre, University of Oxford.

Malischewski, C. A. (2016). Refuge at the crossroads: Social and territorial dynamics of integration in Northern Ireland. In M. Poteet \& S. Nourpanah (Eds.), After the flights. The dynamics of refugee settlement and integration (pp. 21-43). Cambridge: Cambridge Scholar Publishing.

Marger, M. N. (1989). Asians in the Northern Ireland economy. Journal of Ethnic and Migration Studies, 15(2), 203-210.

McCall, L. (2005). The complexity of intersectionality. Signs, 30(3), 1771-1800.

McClintock, A. (1995). Imperial leather: Race, gender and sexuality in the colonial contest. London: Routledge.

McGarry, J., \& O'Leary, B. (2006). Consociational theory, Northern Ireland's conflict, and its agreement 2. What critiques of consociation can learn from Northern Ireland. Government and Opposition, 41(2), 249-277.

McNulty, M. (2016). Refugees in Northern Ireland. Belfast: Embrace.

McVeigh, R., \& Rolston, B. (2007). From Good Friday to good relations: Sectarianism, racism and the Northern Ireland state. Race \& Class, 48(4), 1-23.

Montague, R., \& Shirlow, P. (2014). Challenging racism: Ending hate. Belfast: Policing and Community Safety Partnership.

Murphy, F., \& Vieten, U. M. (2017). Asylum seekers and refugees' experiences of life in Northern Ireland. 
Belfast: Queen's University, Belfast.

Murphy, F., \& Vieten, U. M. (in press). African asylums seekers and refugees on the island of Ireland. In B. Fanning \& L. Michael (Eds.) Immigrants as outsiders on the island of Ireland. Manchester: Manchester University Press.

Murtagh, B. (2011). Ethno-religious segregation in post-conflict Belfast. The Built Environment, 32(2), 213-225.

O'Dowd, L., \& Komarova, M. (2009). Regeneration in a contested territory: A Belfast case study (Divided Cities/Contested States Working Paper, no. 10). Belfast: School of Sociology, Social Policy and Social Work, Queens University, Belfast.

O'Leary, B. (2005). Debating consociational politics: Normative and explanatory arguments. In S. Noel (Ed.), From power sharing to democracy: Post-conflict institutions in ethnically divided societies (pp. 3-43). Montreal: McGill-Queen's University.

Piekut, A., \& Valentine, G. (2017). Spaces of encounter and attitudes towards difference: A comparative study of two cities. Social Science Research, 62, 175-188.

Police Service of Northern Ireland. (n.d.). Hate motivation statistics. Police Service of Northern Ireland. Retrieved from https://www.psni.police.uk/insidepsni/Statistics/hate-motivation-statistics

Poynting, S., \& Mason, V. (2006). Tolerance, freedom, justice and peace? Britain, Australia and anti-Muslim racism since 11 September 2001. Journal of Intercultural Studies, 27(4), 365-391.

Puar, J. K. (2007). Terrorist assemblages: Homonationalism in queer times. Durham: Duke University Press.

Rooney, E. (2006). Women's equality in Northern Ireland's transition: Intersectionality in theory and place. Feminist Legal Studies, 14(3), 353-375.

Rooney, E. (2007). Engendering transitional justice: Questions of absence and silence. International Journal of Law in Context, 3(2), 173-187.

Russell, R. (2016). International migration in Northern Ireland: An update (Research Paper NIAR 35-15). Belfast: Northern Ireland Assembly. Retrieved from http://www.niassembly.gov.uk/globalassets/ documents/raise/publications/2016-2021/2016/ general/3916.pdf

Said, E. (1978). Orientalism. New York, NY: Patheon Books.

Shirlow, P. (2006). Belfast: The 'post-conflict' city. Space and Polity, 10(2), 99-107.

Smyth, L., \& McKnight, M. (2013). Maternal situations: Sectarianism and civility in a divided city. The Sociological Review, 61(2), 304-322.
Szerszynski, B., \& Urry, J. (2002). Cultures of cosmopolitanism. The Sociological Review, 50(4), 461-481.

Allison Morris. (2018). Syrian refugees speak of housing problems and racist attacks in west Belfast. The Irish News. Retrieved from https://www.irishnews.com/ news/northernirelandnews/2018/07/31/news/ syrian-refugees-speak-of-housing-problems-andracist-attacks-in-west-belfast-1395013

Vieten, U. M. (2008). Intersectionality scope and multidimensional equality within the European Union: Traversing national boundaries of inequality? In D. Schiek \& V. Chege (Eds.), European Union nondiscrimination law: Comparative perspectives on multidimensional equality law (pp. 93-113). Abingdon: Routledge-Cavendish Taylor \& Francis Group.

Vieten, U. M. (2011). Tackling the conceptual order of multiple discrimination; Situating different and difficult genealogies of race and ethnicity. In D. Schiek \& A. Lawson (Eds.), European Union non-discrimination law and intersectionality; investigating the triangle of racial, gender and disability discrimination (pp. 63-76). Farnham: Ashgate.

Vieten, U. M. (2012). Gender and cosmopolitanism in Europe: A feminist perspective. Farnham: Ashgate.

Vieten, U. M. (2016). Far right populism and women: The normalisation of gendered anti-Muslim racism and gendered culturalism in the Netherlands. Journal of Intercultural Studies, 37(6), 621-636.

Vieten, U. M. (2018). The New Year's Eve 2015/2016 public sexual violence debate in germany: Media discourse, gendered anti-Muslim racism and criminal law. In M. Bhatia, S. Poynting, \& W. Tufail (Eds.), Media, crime and racism (pp. 73-92). London: Palgrave Macmillan.

Vieten, U. M., \& G. Valentine (Eds.). (2016). Cartographies of differences: Interdisciplinary perspectives. Bern: Peter Lang Publishers. Retrieved from https:// www.peterlang.com/view/title/36567

Ward, K. (2015). Ending the humiliation of women in Northern Ireland. openDemocracy. Retrieved from https://www.opendemocracy.net/5050/kate-ward/ ending-humiliation-of-women-in-northern-ireland

Wodak, R. (2015). The politics of fear: What right-wing populist discourses mean. London: Sage.

Yuval-Davis, N. (1997). Gender \& nation. London: Sage.

Yuval-Davis, N. (2011). The politics of belonging: Intersectional contestations. London: Sage.

Yuval-Davis, N., \& Vieten, U. M. (2018). Citizenship, entitlement, and autochthonic political projects of belonging in the age of Brexit. In S. G. Ellis (Ed.), Enfranchising Ireland? Identity, citizenship and state (pp. 70-80). Dublin: Royal Irish Academy. 


\section{About the Authors}

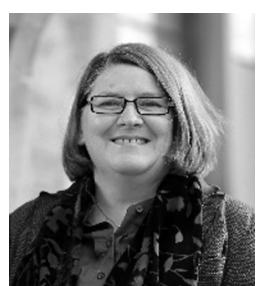

Ulrike M. Vieten is a Sociologist and will be based as a Lecturer in the School of Social Sciences, Education and Social Work, Queen's University Belfast, from July 2019. Her work focuses on situated, constructed and shifting gendered, classed and racialised group boundaries in historical and contemporary perspectives. Ulrike's research and publications span conceptual debates on cosmopolitanisms, far right populisms, racisms and gender in Europe as well as empirical and comparative studies on visible minorities, loss, displacement and refugees. Countries of expertise include England and Northern Ireland, Germany, Austria, Poland, the Netherlands and Turkey. She is author of Gender and Cosmopolitanism in Europe (2012) and co-edited several books such as Cartographies of Differences (2016), and The Situated Politics of Belonging (2006).

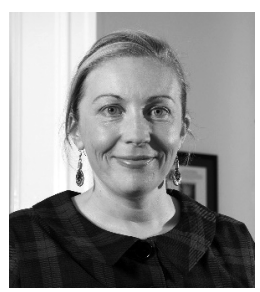

Fiona Murphy is an Anthropologist and Research Fellow in Queen's University Belfast. She specialises in Indigenous politics and movements, refugees and mobility studies, and sustainability in Australia and Ireland. The key thematics in her work include trauma, memory, reconciliation, mobility and integration. She works extensively on the topic of asylum seekers and refugees in Ireland, the UK and Turkey. She is co-author of Integration in Ireland: The everyday life of African migrants (MUP, 2012). She has also written for Allegra: A Virtual Lab of Legal Anthropology Blog, Open Democracy, the Conversation, RTE Brainstorm and the Irish Times. 